centralized approach through which the 21 sectoral programmes are grouped into four clusters; namely: Trade, Industry, Finance and Investment; Infrastructure and Services; Food, Agriculture and Natural Resources; Social and Human Development and Special Programmes.

SADC has made significant progress in implementing its integration agenda since the 1992 Treaty came into force. Since then, more than 20 Protocols to spearhead the sectoral programmes and activities have been signed. Those Protocols that have entered into force include: Immunities and Privileges; Combating Illicit Drugs; Energy; Transport, Communications and Meteorology; Shared Watercourse Systems; Mining; Trade; Education and Training; Tourism; and Health.

Official languages: English, French, Portuguese.

Headquarters: Private Bag 0095, Gaborone, Botswana.

Website: http://www.sadc.int

Email: registry@sadc.int

Executive Secretary: Tomaz Augusto Salomão (Mozambique).

\section{West African Development Bank (BOAD)}

The West African Development Bank (Banque Ouest Africaine de Développement) was established in Nov. 1973 by an Agreement signed by the member states of the West African Monetary Union (UMOA), now the West African Economic and Monetary Union (UEMOA).

Aims. To promote balanced development of the States of the Union and to achieve West African economic integration.

Members. Benin, Burkina Faso, Côte d'Ivoire, Guinea-Bissau, Mali, Niger, Senegal, Togo.

Official language: French.

Headquarters: 68 avenue de la Libération, Lomé, Togo.

Website (French only): http://www.boad.org

Email: boadsiege@boad.org

President: Abdoulaye Bio-Tchané (Benin).

\section{West African Economic and Monetary Union (UEMOA)}

Founded in 1994, the UEMOA (Union Economique et Monétaire Ouest Africaine) aims to reinforce the competitiveness of the economic and financial activities of member states in the context of an open and rival market and a rationalized and harmonized juridical environment; to ensure the convergence of the macroeconomic performances and policies of member states; to create a common market among member states; to co-ordinate the national sector-based policies; and to harmonize the legislation, especially the fiscal system, of the member states.

Members. Benin, Burkina Faso, Côte d'Ivoire, Guinea-Bissau, Mali, Niger, Senegal, Togo.

Headquarters: 01 B.P. 543, Ouagadougou 01, Burkina Faso.

Website (French only): http://www.uemoa.int

Email: commission@uemoa.int

President: Soumaïla Cisse (Mali).

\section{Agency for the Prohibition of Nuclear Weapons in Latin America and the Caribbean (OPANAL)}

The Agency (Organismo para la Proscripción de las Armas Nucleares en la América Latina y el Caribe) was established following the Cuban missile crisis to guarantee implementation of the world's first Nuclear-Weapon-Free-Zone (NWFZ) in the region. Created by the Treaty of Tlatelolco (1967), OPANAL is an inter-governmental agency responsible for ensuring that the requirements of the Treaty are enforced. OPANAL has played a major role in establishing other NWFZs throughout the world.

Organization. The Agency consists of three main bodies: the General Conference which meets for biennial sessions and special sessions when deemed necessary; the Council of OPANAL consisting of five member states which meet every two months plus special meetings when necessary; and the Secretariat General.

Members of the Treaty. Antigua and Barbuda, Argentina, Bahamas, Barbados, Belize, Bolivia, Brazil, Chile, Colombia, Costa Rica, Cuba, Dominica, Dominican Republic, Ecuador, El Salvador, Grenada, Guatemala, Guyana, Haiti, Honduras, Jamaica, Mexico, Nicaragua, Panama, Paraguay, Peru, St Kitts and Nevis, St Lucia, St Vincent and the Grenadines, Suriname, Trinidad and Tobago, Uruguay, Venezuela.

Headquarters: Schiller No. 326, 5th Floor, Col. Chapultepec

Morales, México, D. F. 11570, Mexico.

Website: http://www.opanal.org

Email: info@opanal.org

Secretary-General: Gioconda Úbeda Rivera (Costa Rica).

\section{Andean Community}

On 26 May 1969 an agreement was signed by Bolivia, Chile, Colombia, Ecuador and Peru establishing the Cartagena Agreement (also referred to as the Andean Pact or the Andean Group). Chile withdrew from the Group in 1976. Venezuela, which was actively involved, did not sign the agreement until 1973. In 1997 Peru announced its withdrawal for five years. In 2006 Venezuela left as a result of Colombia and Peru signing bilateral trade agreements with the USA.

The Andean Free Trade Area came into effect on 1 Feb. 1993 as the first step towards the creation of a common market. Bolivia, Colombia, Ecuador and Peru have fully liberalized their trade. A Common External Tariff for imports from third countries has been in effect since 1 Feb. 1995.

In March 1996 at the Group's 8th summit in Trujillo in Peru, the then member countries (Bolivia, Colombia, Ecuador, Peru, Venezuela) set up the Andean Community, to promote greater economic, commercial and political integration between member countries under a new Andean Integration System (SAI).

The member countries and bodies of the Andean Integration System are working to establish an Andean Common Market and to implement a Common Foreign Policy, a social agenda, a Community policy on border integration, and policies for achieving joint macroeconomic targets.

Organization. The Andean Presidential Council, composed of the presidents of the member states, is the highest-level body of the Andean Integration System (SAI). The Commission and the Andean Council of Foreign Ministers are legislative bodies. 